\title{
Gender Control in Forest Product Value- Chain in Rivers and Bayelsa State, Nigeria
}

\author{
Olaleye S. M. ${ }^{1 *}$ and Agbeja B. $0{ }^{2}$
}

1Department of Forest Resources Management, University of Ibadan, Nigeria.

${ }^{2}$ Department of Forestry and Wildlife Management, University of Port Harcourt, Choba, Rivers State, Nigeria.

\section{ARTICLE INFO}

Article No.: 012014050

DOI: 10.15580/GJAS.2014.2.012014050

Submitted: $20 / 01 / 2014$

Accepted: 25/03/2014

Published: 27/03/2014

${ }^{\star}$ Corresponding Author

Olaleye S. M.

E-mail:sele.olaleye@yahoo.com

\section{Keywords:}

Value, control, processing, crafts,

Bayelsa, small enterprise,

extension education
Forest Products (FPs) are numerous and exhaustive processing of some species adds to the number of utilization. Apart from timber, non-timber forest products have the potential to increase under innovative modifications and introduces small-scale enterprises (SSE) from the point of collection, through the value-chain channel and finally to the end-users (consumers). This study was carried out to examine the impact of gender in selected FPs with a view to creating a paradigm shift in gender control (GC) and value-chain adjustment in forest conservation, harvesting, processing, marketing and consumption of FPs in Bayelsa and Rivers State, Nigeria.

The result reveals that the more the married females and investors in a particular state the less the GC activities in FPs. Respondents between ages 20 and 59 and high level of education resulted to less GC commitment than younger or older ones with low level of education. More so, results revealed that frequent involvement of females in fruit and vegetable FPs are likely to discourage GC activities. The control of gender also shows that medicinal plant and crafts would offer positive and innovative mechanism to sustainability of livelihood and forest management. In Rivers, females dominate in handling of fruit and vegetable FPs while in Bayelsa, there was no gender restriction. In some FPs, children are a set of gender due to adult sentiments to distribution. In addition household, musical and fishing crafts were products from choice of FPs.

Gender control in value-chain activities encourages SSE and innovation. Forest extension education would enhance efficiency. 


\section{INTRODUCTION}

People attach different importance to forest products (FPs) such as timber and non-timber forest products that are capable of providing and increasing income, using cheap labour and life sustaining. This is due to the fact that collection is free, increasing demand, requires risible collection and processing tools, less taxation and infrastructure.

FPs are numerous as well as the control and access over them. This can be observed in the collection, processing or marketing activities. In general, the word access in forestry refers to right to entry or use the natural resources which involves processes by men and women in the collection, processing or marketing of these resources whether individually or collectively (Chanthalangsy, 2009).

FPs are used as vegetables in most African dishes and in traditional medicine, medicine plants, crafts, fuelwood and nursery operations. FPs has direct and indirect uses and several small-scale enterprises have emerged as a result of good benefit from value addition and distribution. For some, men take to difficult task especially during collection while women have the privilege of simple task such as packaging and marketing. Unfortunately, the marketing of FPs in Nigeria is done in most unorganized markets. Producers are likely to produce more if they are able to sell at reasonable prices (Popoola and Rahji, 2001). Although, forests are less considered during valuation, studies have revealed that they play significant roles in food security and ethno-medical use. This implies that FPs have being in existence before civilization and man has been a wasteful devourer of the forest. Now that climate change have continued to affect man, man have come to the realization that the forest is the only way out since its resources are renewable. The activities of forest exploiters have become a concern to the state, nation and the world at large. Conservation and sustainability are now in the front lines of media reports advocating for the efficient use of the remaining forest. One of the ways of achieving this is by tracing the gender control mechanism in the value chain of each forest species and its by-product. The understanding of the position and behavior of the actors such as gender is very important to improve marketing. Tevelde et al . $\left(\begin{array}{llll}2 & 0 & 0 & 6\end{array}\right)$ revealed that certain key entrepreneurs (collectors and processors) are driving force of success through several non-timber forest products value chains in both Bolivia and Mexico. Processors own small enterprises that need support in the commercialization of FPs.

In Nigeria, small enterprises in FPs are emerging especially in local areas. These enterprises though small in capacity have over the years been source of sustainable livelihood. Larinde (2003) and Warizeribe (2013) identified several enterprises by men and women in forestry. These enterprises include: fuelwood gathering; basket industry which includes household craft and fishing craft; musical crafts; carving industry; weaving industry; poles trading; wild fruit trading; medicinal plant trading; trade in wild vegetables; seedling production; charcoal production; oil Palm production; palm wine and local gin production; and rubber factory.

This paper investigated the gender control in value chain of FPs in Bayelsa and Rivers State with a view of eliciting information on areas of priority, innovation, improvement and valuation of forest products to Small enterprise and intending forest industries.

\section{METHODOLOGY}

This study covered four local government areas in Bayelsa and Rivers State. Two communities were selected in each LGA. This is because they are very near to forest and have access to markets in the cities which they feed. The annual rainfall of this area is $3000 \mathrm{~mm}$, temperature of $24-27$ degrees and in the region between latitude $4^{\circ} 30^{\prime} \mathrm{N} 7^{\circ} 03^{\prime} \mathrm{E}$. A set of structured questionnaire were purposefully administered to 120 respondents from twelve (12) communities in both states. Respondents dealing with forest products collection and enterprise were selected from each community. The questionnaire considered the demographic characteristics of respondents, gender control and value chain of selected FPs. Descriptive statistics was carried out on the collected data.

\section{RESULTS AND DISCUSSION}

\section{Demographic Characteristics of Respondents}

Demographic information of respondents in table 1 shows the characteristics of sampled respondents in the study area. The sex distribution indicates that majority of the respondents in the two states were females with 58.9 percent in Bayelsa and 69.0 percent in Rivers. This implies that females dominate in forest product activities which may be due to nature of the forest or household provisioning but with the males also involved revealed that there was no gender sensitivity. Generally, women constitute a large labour force in forestry field operations, especially in the areas of species recognition, collection, gathering, processing, marketing and use of NTFPs (Warizeribe, 2013). Furthermore, in table 1, the age distribution shows that majority of the respondents were found to be between 40-59 years, 29.4 percent were females and 20.7 percent males in Rivers while in Bayelsa, both males and females were 19.6 percent. This was closely followed by respondents between ages 20-39 years. Females 28.6 percent and 25.9 percent in Bayelsa and Rivers respectively were the highest. Interestingly, in both age ranges especially between 20 39 years, most of the respondents were females. However, this implies that the active age group practicing and influencing forestry activities were among 
young men and women because the numbers of respondents reduced with increase in age. CIFOR (2006) also declared that with the potential to revert the current trend of aged people, the approach to active participation should involve characterization of individuals involved in FPs, indigenous knowledge system and practices. However, some respondents, mostly females could not disclose their ages.

Table 1: Frequency Distribution of Demographic Characteristics of Respondents

\begin{tabular}{|c|c|c|c|c|}
\hline \multirow{2}{*}{$\begin{array}{l}\text { Demographic } \\
\text { Characteristics }\end{array}$} & \multicolumn{2}{|c|}{ Bayelsa $=56$} & \multicolumn{2}{|c|}{ Rivers $=58$} \\
\hline & Male (\%) & Female (\%) & Male (\%) & Female (\%) \\
\hline \multicolumn{5}{|l|}{ Age } \\
\hline Below 20 & 1.8 & - & - & - \\
\hline $20-39$ & 17.9 & 28.6 & 3.4 & 25.9 \\
\hline $40-59$ & 19.6 & 19.6 & 20.7 & 29.4 \\
\hline 60 and above & - & 1.8 & 3.4 & 5.2 \\
\hline None & 1.8 & 8.9 & 3.4 & 8.6 \\
\hline \multicolumn{5}{|l|}{ Marital Status } \\
\hline Single & 7.1 & 3.6 & 3.4 & 1.7 \\
\hline Married & 30.4 & 35.7 & 12.1 & 44.9 \\
\hline Widowed & - & 5.3 & 1.7 & 3.4 \\
\hline None & 3.6 & 14.3 & 13.8 & 19.0 \\
\hline \multicolumn{5}{|c|}{ Educational Level } \\
\hline Primary & 17.9 & 25.0 & 10.3 & 34.5 \\
\hline Secondary & 16.1 & 16.1 & 8.6 & 34.5 \\
\hline ND / B.Sc & 7.1 & 7.1 & 1.7 & - \\
\hline None & - & 10.7 & 10.3 & - \\
\hline \multicolumn{5}{|l|}{ Family Size } \\
\hline $1-4$ & 10.7 & 5.3 & 6.9 & 19.0 \\
\hline $5-8$ & 14.3 & 23.2 & 6.9 & 12.1 \\
\hline 9 and above & 1.8 & 1.8 & 3.4 & - \\
\hline None & 14.3 & 28.6 & 13.8 & 37.9 \\
\hline
\end{tabular}

Field survey, 2013

The frequency distribution of the marital status in table 1 also revealed that most of the females especially in Rivers (44.9\%) were married while among the singles the highest was $7.1 \%$ in Bayelsa. Overall, majorities were married although few of the respondents were widows in both states and were mostly females. This indicates that majority of the respondents have high level of responsibility to their homes and capable of discharging duties that can enhance sustainability of forest and business in spite of the condition of their marriage. In addition, some respondents, mostly females were unable to disclose their marital status.

In education, table 1 showed that most of the female respondents had primary education, $34.5 \%$ percent in Bayelsa and $25.0 \%$ in Rivers while 34.5 percent had secondary education in Rivers. Overall, the highest form of education (ND / B.Sc) was noticed in Bayelsa and certainly not in forestry which revealed that education have impact in forestry activities while respondents without formal education in Bayelsa and Rivers revealed that poverty and mis-use of forest resources. This shows that the level of education in forestry is still a major factor in sustainability as it has influence in the effective transaction and proper record keeping (Ogunwande et. al, 2009).

The table 1 also revealed the highest family size of $5-8$ persons $(23.2 \%)$ in the study area and interestingly majority were females in Bayelsa. Males had the highest number of children which indicates polygamy. In addition, majority of the women did not disclose their family size which could be due to fears that this information might disorganize the value-chain and enterprise. This demographic information shows a typical scenario of the rural mentality but with so much potential for project adoption.

\section{Gender Control and Value-chain of Forest Products in Study Area}

People attach high value to FPs and desire to consume them but have little or no time to conserve them on their own even when it's possible. Marketing of some FPs begins from the points of collection, processing, packaging, display. Table 2 shows the frequency distribution of gender control in collection, small enterprise, and marketing of selected FPs. Each 
respondent were requested to mention five (5) FPs commonly used by them. Results reveal that ten (10) of the FPs were mentioned by only females with the highest in Monodora myristica and Brachystegia eurycoma Harms, ten (10) by females and children with the highest in Gnetum africanum, nine (9) by male, female and children with highest in Garcina cola Heckel, eight (8) by only males with the highest in Raffia hookerii and seven (7) by males and females with the highest in Theobroma cacao and fishing craftwork. None of the FPs was exclusively controlled by children or males and children. This results implies that females and children were more interested in the use of vegetables and fruits, males take to more tasking (in collection and processing) FPs which conforms to Chanthalangsy (2009) that both men and women collected the same types of NTFPs except for those that were difficult to collect or were sourced out from very far areas such as wild animals, bee hives, red ants' nest, and some rattan which were collected only by the men, while some males as well as females are involved in craftwork and medicinal plants which is in agreement with Warizeribe (2008) that males and females generate extra income through craftwork. The FPs utilized by all gender were non-timber forest products that require little or no value addition before its consumption and marketing. This is in conformity with UNDP (2001), which states that the share of NTFPs to household income could reach up to $80 \%$ in poor locality or low income jobs.

The FPs in table 2 were categorized and described under the sub-headings fruits, vegetable, medicinal barks, seeds and herbs and craft FPs. The value-chain in most of the FPs was also discussed in table 2.

Table 2: Frequency Distribution of Gender Control in Collection, Small Enterprise and Marketing of Forest Products

\begin{tabular}{|c|c|c|c|c|c|c|}
\hline \multirow{2}{*}{$\begin{array}{l}\text { Local / Common } \\
\text { Names }\end{array}$} & \multirow{2}{*}{$\begin{array}{l}\text { Scientific Names / tree } \\
\text { source }\end{array}$} & \multirow{2}{*}{$\begin{array}{l}\text { States where } \\
\text { mentioned }\end{array}$} & \multirow[t]{2}{*}{ Main Uses } & \multicolumn{3}{|c|}{ Gender Control } \\
\hline & & & & Male & Female & Children \\
\hline Palm oil tree & Elaeis guineensis & BsRs & $\begin{array}{l}\text { Medicinal, craft, fruit, } \\
\text { fuelwood, oil } \\
\text { production, }\end{array}$ & 12 & 5 & 1 \\
\hline Palm wine tree & Raffia hookerii & BsRs & $\begin{array}{l}\text { Medicinal, gin and } \\
\text { wine production, } \\
\text { crafts, }\end{array}$ & 8 & - & - \\
\hline Bush mango & $\begin{array}{l}\text { Irvingia gabonensis } \\
\text { (Aubry-Lecomte) Baill. }\end{array}$ & BsRs & $\begin{array}{l}\text { Fruit, Fuelwood, } \\
\text { medicinal, soil } \\
\text { fertility, oil, }\end{array}$ & 1 & 8 & 1 \\
\hline Waterleaf & Talinum triangulare & BsRs & Vegetable, medicinal & - & 14 & 1 \\
\hline Snail & Acatina marginata & BsRs & & 6 & 3 & 5 \\
\hline Bitter cola & Garcina cola Heckel & BsRs & $\begin{array}{l}\text { Medicinal, fruit, } \\
\text { culinary, }\end{array}$ & 2 & 13 & 3 \\
\hline Sweet cola & Cola pachipata & BsRs & Fruit, medicinal & - & 4 & 1 \\
\hline Cocoa & Theobroma cacao & BsRs & $\begin{array}{l}\text { Fruit, medicinal, } \\
\text { nursery shade }\end{array}$ & 1 & 4 & - \\
\hline Allegator pepper & $\begin{array}{l}\text { Aframomum } \\
\text { meleguetaK. Schum }\end{array}$ & BsRs & $\begin{array}{l}\text { Spice, flavour, } \\
\text { medicinal (stimulant) }\end{array}$ & 4 & 5 & 1 \\
\hline African nutmeg & Monodora myristica & Bs & Spice, medicinal & - & 6 & - \\
\hline Calabash & Crescentia cujete & Bs & Calabash utensils & 3 & 2 & - \\
\hline Cane & $\begin{array}{l}\text { Eremospartha } \\
\text { macrocarpa }\end{array}$ & Bs & $\begin{array}{l}\text { Craft, framework } \\
\text { construction }\end{array}$ & 1 & 2 & - \\
\hline Avogador pear & Persea americana Mill. & Rs & $\begin{array}{l}\text { Fruit, culinary, } \\
\text { medicinal }\end{array}$ & 1 & 1 & - \\
\hline African breadfruit & Trecular africana & Bs & Food, medicinal & - & 7 & 1 \\
\hline Oil bean & Pentaclethra macrophylla & Bs & $\begin{array}{l}\text { Food, medicinal, oil, } \\
\text { timber, apiculture }\end{array}$ & - & 2 & 1 \\
\hline Coconut & Cocos nucifera & BsRs & $\begin{array}{l}\text { Fruit, milk, medicinal, } \\
\text { ornamental }\end{array}$ & 2 & 3 & 1 \\
\hline Local pear & $\begin{array}{l}\text { Dacryodes edulies (G. } \\
\text { Don) Lam H.J. }\end{array}$ & BsRs & $\begin{array}{l}\text { Fuelwood, fruit, } \\
\text { medicinal, apiculture, } \\
\text { ornamental }\end{array}$ & 1 & 12 & 1 \\
\hline Pterocarpus (Oha) & Pterocarpus soyauxii & Rs & Medicinal, vegetable & - & 2 & - \\
\hline Dogoyaro & Azadirachta indica & BsRs & Medicinal & 1 & 2 & \\
\hline Mango & Mangifera indica Linn & BsRs & $\begin{array}{l}\text { Fruits, medicinal, } \\
\text { fuelwood }\end{array}$ & - & 1 & 1 \\
\hline Star apple & Christophylum abidum & BsRs & $\begin{array}{l}\text { Fruit, culinary, } \\
\text { medicinal, fuelwood }\end{array}$ & - & 1 & 1 \\
\hline Okazi (Igbo) & Gnetum africana & Rs & Medicinal, culinary, & - & 16 & 1 \\
\hline
\end{tabular}




\begin{tabular}{|c|c|c|c|c|c|c|}
\hline & & & vegetable & & & \\
\hline Pepper fruit & Denietta tripetels & Bs & Culinary, medicinal & - & 1 & 1 \\
\hline Orange & Citrus sinensis & BsRs & $\begin{array}{l}\text { Fruits, medicinal, } \\
\text { ornamental }\end{array}$ & - & 9 & 1 \\
\hline Colanut & $\begin{array}{l}\text { Cola acuminata (P. } \\
\text { Beauo) Schott et Endl. }\end{array}$ & BsRs & $\begin{array}{l}\text { Fruits, medicinal, } \\
\text { fuelwood, culinary }\end{array}$ & 3 & 3 & 2 \\
\hline Sour sop & Anona muricata & Rs & $\begin{array}{l}\text { Fruit, medicinal, } \\
\text { ornamental culinary }\end{array}$ & - & 1 & - \\
\hline Plum & Prunus cerasifera & Rs & Fruit, medicinal & 1 & 4 & 1 \\
\hline Wrapping leaf & Thaumatococcus daniellii & Rs & $\begin{array}{l}\text { Medicinal, craftwork, } \\
\text { storage }\end{array}$ & - & - & 1 \\
\hline Achi (Igbo) & $\begin{array}{l}\text { Brachystegia eurycoma } \\
\text { Harms }\end{array}$ & BsRs & Food, medicinal & - & 6 & - \\
\hline Guava & Psidium guajava & Rs & $\begin{array}{l}\text { Fruit, culinary, } \\
\text { medicinal, } \\
\text { ornamental }\end{array}$ & - & 3 & 1 \\
\hline Hot leaf & Piper guineense & Rs & $\begin{array}{l}\text { Medicinal, culinary, } \\
\text { vegetable spice }\end{array}$ & - & 1 & - \\
\hline Rubber & Hevea brasiliensis & Rs & Latex & 1 & - & - \\
\hline Red local apple & & Rs & Fruit, shade & - & 3 & - \\
\hline Walnut & Coula edulis Baillon & Rs & Food, pole, medicinal & - & 1 & - \\
\hline Wild carrot & Daucus carota & Rs & Fruit, medicinal & 1 & - & - \\
\hline Bamboo & Bambusa vulgarins & Bs & $\begin{array}{l}\text { Craft, construction, } \\
\text { food, medicinal }\end{array}$ & 1 & - & - \\
\hline Scent leaf & Ocimum gratissimum & Rs & Medicinal, vegetable, & - & 2 & - \\
\hline Black spice & Mucuna sloanei & Rs & $\begin{array}{l}\text { Soup condiment, } \\
\text { medicinal }\end{array}$ & - & 3 & - \\
\hline Bitterleaf & Vernonia amygdalina & BsRs & Medicinal, vegetable & - & 2 & - \\
\hline Honey & NA & Rs & $\begin{array}{l}\text { Medicinal, beverage, } \\
\text { jam , wax }\end{array}$ & 2 & - & - \\
\hline Bushmeat & Local tortoise, squirrel, & BsRs & $\begin{array}{l}\text { Meat, animal skin, } \\
\text { Medicinal }\end{array}$ & 2 & - & - \\
\hline Household crafts & Palm trees, rattan & BsRs & $\begin{array}{l}\text { Mat, basket, mortar \& } \\
\text { pestle, local filter, } \\
\text { local sponge }\end{array}$ & 2 & 1 & - \\
\hline $\begin{array}{l}\text { Medicinal bark, } \\
\text { roots \& herbs }\end{array}$ & NA & BsRs & Medicinal & 1 & 1 & - \\
\hline Musical craft & Mangrove & BsRs & Local flute and drum & 1 & - & - \\
\hline Charcoal & NA & BsRs & Fuel & 1 & - & - \\
\hline Local broom & Tree branches & Rs & Sweeping craft & - & 1 & 1 \\
\hline Fishing Craftwork & Rattan, bamboo & Bs & Fishing, smoking & 2 & 4 & - \\
\hline
\end{tabular}

Note: Igbo - ethnic group in Eastern, Nigeria. Bs and Rs represent Bayelsa and Rivers state. Field survey, 2013.

Fruits FPs: Mangifera indica, $C$. pachipata, $I$. gabonensis, C. abidum, T. cacao and C. sinensis are fruits collected from the wild. Males, females and children collected these fruits at various locations but sometimes they are collected individually. They are collected by hand pull and poles. Cola pachipata and $T$. cacao are decreasing in quantity due to the fact that only the juice are consumed and the seeds (reproductive part) were thrown away except $I$. gabonensis where the reverse was the case. This is because there was no policy or regulation on sustainable use and conservation of these fruits. This is in agreement with Alamu, (2011) that a policy is therefore seen as an expression of a number of decisions based on exigencies of the time the policy is formulated therefore it should be flexible enough to accommodate likely changes in the course of its use. These fruits are all eaten fresh. Fruits of $M$. indica, I. gabonensis, C. abidum and C. sinensis have different varieties and sizes that commands cost effect and as a result are quickly sold no matter the cost or left to rot if variety was not desirable. Apart from cost they are also domesticated around the home for easy access and control. The leaves of $M$. indica and $C$. sinensis are used as part of the raw materials for preparing malaria medicine. Only the seeds of $I$. gabonensis were either sun dried or smoke dried and are used in soup condiment. Though available all year, the seeds are expensive and more expensive during the dry season. The fruits of $I$. gabonensis are scarcer because the seeds were the ones collected during expedition for easy 
carriage. Fruits of $P$. macrophylla were processed into food condiment; they have pleasant flavors that spice up meals. Processing is rudimental which involves cooking, dehulling and fermentation. Apart from these, high wood consumption for fuel and timber has resulted to further low production and cost. Processed beans are better wrapped up in leaves of Thaumalococcus plant. There is increase in the consumption and sale of $P$. macrophylla, as observed by Agbogidi and Okonta (2003), which can be attributed to its known aid to hemoglobin formation in the body. Also, due to the nature of the wood pods, availability of fruits is persistent throughout the year. Also farmers protect it in agroforestry practice which accounts for its availability for fuel, food and medicine uses.

Value Chain of Fruit Forest Products: Gatherers are made up of rural people who embark on expeditions comprising of individuals, different age groups and villages to a sorting point where desirable varieties were separated for value addition, then to wholesalers. Single FP plantations are not popular sites so sellers may have to move from one household to another depending on their carrying capacity such as sack bags, baskets and wheel barrow to community market. From here buyers are seen with pick-up vans heading for the urban markets to the retailers. Prices are determined by middlemen at every market except retailers who in most cases have the benefit of selling at a good price. Producers are likely to produce more if they are able to sell at reasonable prices (Popoola and Rahji, 2001). For oil bean, gatherers (usually women) process the products before selling to wholesalers who will have to battle with storage and spoilage.

Vegetables FPs: $G$. africanum, $P$. soyauxii, $P$. guineese and $H$. crinata were wild vegetables collected from the forest. The parts collected were the shoots and seed (Gnetum). P. soyauxii was collected from the young branches of its tree while $G$. africanum and $P$. guineese are climbers. These vegetables are known for their herbaceous flavor and impart in soup. In Rivers states, the leaves of $G$. africanum are fibrous and used for special delicacies, and sometimes waterleaf (Talinum triangulare) is added to soften its fiber. P. guineese imparts heat and spicy aroma in soup. H. crinata is known for its beautiful aroma along, after and lasting sweet taste. All are domesticated around the household for easy access and income. These were collected by cutting as the shoots appear and no processing is needed. They are used in soup and herbs preparation for medicinal purpose and were sold either in the rural and urban markets. The supply of these vegetables are stable because there shoots easily grow back.

Value Chain in Vegetable Forest Products: Women are the sole distributors of vegetable FPs. From the point of harvesting, they are tied in bundles then straight to retailers. The availability and decision of pricing and marketing of $G$. africanum depends on gatherers. The price of $G$. africanum increases as processing continues. It is sliced into smaller bits then grinded into thick paste, charges are place on each stage. Also due to the fibrous nature, it can be sliced, sun dried and stored in dry places. It can also be used for culinary purpose that is, served as edible herbs. Further processing in these vegetables reduces the cost prices.

Medicinal Barks, Seeds and Herbs FPs: The efficacy of medicinal herbs is a challenge to orthodox medicine as indigenous people has used them for centuries. Among the medicinal trees, the stem barks decoction of P. macrophylla has a history of local medicine preparation for malaria and chest related ailment treatment respectively. Sales depend on the media for efficacy. $B$. eurycoma gum is mixed with snail mucin and honey in low concentration for wound healing (Adikwu, 2007). D. tripetels are edible fruits collected between April - June for its peppery spicy taste. It produces a mild stimulant effect when chewed. P. guineese and $A$. melegueta are edible herbs and are best when eaten fresh. The problems with these herb arises when the growing season are over. They are better dried, stored in airtight containers and used as spice, flavor and stimulant and also sold for income. In addition, the medicinal plants were more of the reproductive part (seeds) which is not a sustainable practice as indicated by Jimoh (2005) that in a number of species, the reproductive organs are extracted for medicinal purpose and to reasonable income leaving little or no consideration for sustainability of the species. The seeds of $A$. melegueta are sold as well as the grains and become more expensive when dried. Good traditional practitioners of medicine rely on efficacy of $A$. melegueta. Alcohol (dry gin), palm wine and $A$. melegueta were essential parts in numerous traditional and ceremonial occasions. The traditional practitioners rely on dry gin, water or lime juice as media for efficacy of medicinal bark decoctions.

Value Chain of Medicinal Plants: The trade of medicinal FPs and dry gin in the study area were complimentary. Since processing was done at home, selling begins also from this point. Men sellers are more static than women and in most cases not in market places. Women sellers are seen with several tree barks in bottles or spread in platforms after drying. The form of processing was by cutting into smaller pieces. Hawkers sell mixed barks and their number is increasing by the day due to patronage. Sellers also rely on supplies from different destinations (Eastern, Western and Northern Nigeria).

Crafts Forest Products: Elaeis guineensis has numerous functions and extractions. Apart from the use for red oil and craftwork, the extraction of kernel oil is a specialized area completely handled by different processors. Financially, this tree is regarded as the most costly economic tree. Also its purpose extends to raising of seedlings and marketing them. Edible weevils are 
sometimes found on dead husk which are processed and sold on stakes at road-sides and bars. The young stems were also used in religious worship and a sign for restrictions of persons around properties.

Raffia hookerii: Alcohol are produced from palm wine of $R$. hookerii and used as compliment with tree bark for medicinal purpose. The palm wine is also served in place of larger beer. Marketing is done by bar operators, hawkers and roadside market. In the study area, women control the bars while the males control the hawking. It's also used for craftwork. The products from these FPs range from primary, secondary and salvage products and sales depend on the purpose of the end-use product. Raffia products have several dimensions to its use.

Eremospartha macrocarpa: The varieties of rattans found in these areas were E. macrocarpa and $C$. deerratus whose cane and shoots were collected from the forest all year round. Collection is by cutting the cane. The local people had difficulty in harvesting them because of snakes and ants. The matured parts are found lying on the ground. Processing of rattan depends on the end uses. A lot of value addition is involved, ranging from scraping, sorting, splitting, drying and or heating and varnishing or dying while the waste are used as fuel.

Value Chain of Craft Forest Products: Oil palm tree small scale industries are sited in plantations or homes. During harvesting difficult tasks were done by the men due to the nature of labour while the women were gathers of leftovers and salvage products (leaves). This is in line with Carr (2008) that these tasks are important within the context of local/domestic markets, they become crucial in supplying global markets and require a mix of skills and resources from a range of actors. The range and mix vary from product to product and from place to place.

Women have more impact in the marketing of all stages of products from this tree as well as controlling the prices. Raffia hookerii small-scale enterprises are sited in plantations or homes in some parts of Bayelsa and Rivers states. Most craft products produced from raffia are used for domestic purpose (often seen and sold at homes) which was due to the nature of raffia. Dry gin production from raffia wine is a small enterprise monopolized and attributed to the people of Akwa-lbom and Cross River states in areas (Southern Nigeria) dominated by raffia. Rattan products are used in households and sold as finished products in markets and shops. The increase in timber cost has resulted to the thriving of local craft industries that now produce elegant furniture and decorations. The private sectors derive more revenue in craft industry enterprise as observed by Tee (2010). Furniture industries in Rivers states buy the raw materials from Cross Rivers, though very cheap but transportation and fabrication effect are quite challenging. Investigation revealed that there is little or no strategic management plan for FPs during seasonal fruiting, while the ones going extent were not preserved or maintained (Warizeribe, 2013). Overall men are in charge of household and musical crafts in Rivers due to the task of collection, transportation, processing and marketing but in Bayelsa, both men and women are involved in fishing crafts.

Wildlife FPs: Animal forest products such as honey and bush meat were occasional expeditions for men except snail expedition where women and children are involved. The task of collecting and processing honey and bush meat were men's privilege. What constitute bush meat are different types of animals such as squirrel, bush rat, porcupine, fruit-bat, antelope, grasscutter, monitor lizard, snake, crocodile and local tortoise. Several products are obtained after processing apart from marketing of whole product. However, all are sold by women in both states otherwise the products are cheapened.

\section{CONCLUSION}

The importance of FPs to the welfare of the rural poor cannot be over emphasized and this is revealed in the level of gender control measures in roadside markets and small enterprises. Forest extension and education activities would be successful if it counts on the indigenous knowledge, active age groups, frequency of gender control, value addition as well as the value chain of products from the point of collection to the final consumer. Marital status and educational level of the respondents are important factors in influencing gender role and innovative development. Females in FPs enterprise are voiceless extension entrepreneurs of direct-use or consumable products, that is, their impacts in the society and informal economy are not recognized even as major handlers of Forest products. The implication is that the levels of innovations are inadequate and can't withstand the national and international standards. This is as a result of poor certification, value addition and valuation, lack of new products, new markets. Sustainable development incorporates the valuing, gender activities, collectors, processors, institutional inputs and the FPs. Each of these FPs has its unique way of distribution and the channels sometimes create gender difficulties (for instance, gin enterprise). Fruit and vegetable FPs were more mentioned and expresses the place of more activities in the marketing of FPs. The implications of these activities are overexploitation, deforestation, increasing poverty incidence, climate change and unsustainable use of the forest resource. Having worked on major types of FPs, gender control and value chain of mentioned FPs in Bayelsa and Rivers, other areas of interest need are proper valuation and market survey. Interested forest extension researchers could carry on with the work in these areas. 


\section{REFERENCES}

Adikwu, MU, (2007). The evaluation of snail mucin dispersed in Brachystegia gum gel as a wound healing agent. Animal Research International 4 (2):685-690.

Agbogidi, OM, Okonta, BC, (2003). Role of women in community forestry and environmental conservation. In: S. O. Akindele and L. Popoola (eds). Proceedings of the 29 Annual Conference of Forestry Association of Nigeria, Calabar, Cross River State, Nigeria. P 101-111.

Alamu, LO, (2011). Forest policy compliance on desertification control in North Central Nigeria. Ph.D Thesis submitted to the Department of Forest Resources Management, Faculty of Agriculture and Forestry, University of Ibadan, Ibadan.

Carr, M, (2008). Gender and non-timber forest products. Promoting food security and economic empowerment by the International Fund for Agricultural Development (IFAD), August 2008.

CIFOR (2006). Non-timber forest products limitations and importance. Accessed at (www.cifor.cgiar.org/publications/).

Chanthalangsy, N, (2009). Gender roles in utilization of NTFPs in Na Mo Villages, Oudomxay Province, MSc Dissertation, Faculty of the Graduate School, University of the Philippines Los Baños, Department of Social Forestry and Forest Governance.

Jimoh, SO, (2005): Non-timber forest products in phytomedicine and culinary uses in Nigerian. J. For.Vol. 35 (1).25-38.

Larinde, SL, (2003). Participation or rural women in forestry activities. And In: S. O. Akindele and L. Popoola (eds). Proceedings of the $29^{\text {th }}$ annual conference of Forestry Association of Nigeria (FAN) held in Calabar. Cross River State, Nigeria, pp 174177.

Ogunwande, OA, Jimoh, SO, Asinwa, IO and Adegoke, FF, (2009). Survey and comparison of market prices of selected NTFPs in Osun and Oyo state. Obeche Journal of the Tree Club, Vol. 28 (1) 22.

Popoola, L, and Rahji, MAY, (2001). Spatial market integration test of Terminalia ivorensis sawn wood markets in Nigeria. J. Tropical Forest Products 7 (1) 1-9.

Tee, NT, (2010). Marketing and utilisation of non-timber forest resources and implications for sustainable forest management in the tropics. Readings in sustainable tropical forest management. Essays in honour of Professor Labode Popoola. Pp 263-276.

Tevelde, DW, Rushton, J, Schreckenberg, K, Marshall, E, Edouard, F, Newton, A, Arancibia, E, (2006). Entrepreneurship in value chains of non-timber forest products.Accessed at www.unepwcmc.org/entrepreneurship-in-value-chains-of-nontimber-forest-products_302.html.

United Nations Development Programme (UNDP) (2001). Human Development Report 2001, New York, United Nations Development Programme.

Warizeribe, SM, (2013). Gender role in sustainable management of non-timber forest products in SouthSouth, Nigeria. Ph.D thesis submitted to the Department of Forest Resources Management, University of Ibadan, Ibadan Nigeria.

Warizeribe, SM, (2008). Socio-economic impact of community forestry in Iwokiri Integrated Mangrove Resources Centre in Bolo, Rivers State. Unpublished M.Phil Thesis Report, Department of Forest Resources Management. University of Ibadan, Ibadan. Nigeria. 